\title{
The effect of biorational insecticides on the citrus aphids and their predator, Coccinella septempunctata L.
}

\author{
Behnam AMIRI BESHELI ${ }^{1,2}$, Amir HosseinTOORANI ${ }^{3}$, Habib ABBASIPOUR ${ }^{3}$
}

Received November 11, 2018; accepted October 15, 2019. Delo je prispelo 11. novembra 2018, sprejeto 15. oktobra 2019.

The effect of biorational insecticides on the citrus aphids and their predator, Coccinella septempunctata $\mathrm{L}$.

Abstract: To determine selective effectiveness for specific pesticides on biological control species, we evaluated the contact toxicity of different treatments including $10 \mathrm{ml} \mathrm{l}^{-1}$ dishwashing liquid, Dayabon 5, 6, 7, 8, 9 and $10 \mathrm{ml} \mathrm{l}^{-1}$, Palizin 1.5, 2.5 and $2.5 \mathrm{ml} \mathrm{l}^{-1}$, Palizin 1.5, 2 and 2.5+Citrol oil $5 \mathrm{ml} \mathrm{l}^{-1}$, Tondoxir 2 and $3+$ Bartar soap $1 \mathrm{ml} \mathrm{l}^{-1}$, Malathion $2 \mathrm{ml} \mathrm{l}^{-1}$ and control (water) on the adult aphids of the most important citrus gardens and their predator, Coccinella septempunctata L. in the laboratory conditions. The results revealed that the Palizin treatment $2.5+$ Citrol oil $5 \mathrm{ml} \mathrm{l}^{-1}$, caused the highest rate of the mortality of the citrus green aphid, Aphis spiraecola Patch, 1914 in 36 hours. Concentrations of 7 to $10 \mathrm{ml} \mathrm{l}^{-1}$, Dayabon and Palizin 2.5+Citrol oil $5 \mathrm{ml} \mathrm{l}^{-1}$, as well as $3 \mathrm{ml}^{-1}$ Tondexir + Bartar soap $1 \mathrm{ml}^{-1}$ had the highest mortality of the citrus brown aphid, Aphis citricidus (Kirkaldy, 1907), 36 hours after treatment (100\%). In addition, the treatments of Palizin $2 \mathrm{ml}^{-1}+$ Citrol oil of $5 \mathrm{ml}^{-1}$, as well as $2 \mathrm{ml} \mathrm{l}^{-1}$ Tondexir+Bartar soap $1 \mathrm{ml} \mathrm{l}^{-1}$ and concentrations of $5 \mathrm{ml} \mathrm{l}^{-1}$ and $6 \mathrm{ml}^{-1}$ of Dayabon produced the same amount of the mortality of the citrus black aphid, Toxoptera aurantii (Boyer de Fonscolombe, 1841). Tondexir $3 \mathrm{ml} \mathrm{l}^{-1}+$ Bartar soap $1 \mathrm{ml} \mathrm{l}^{-1}$ in 24 hours after treatment caused the highest rate of the mortality of the cotton aphids, Aphis gossypii Glover, 1877 (83.88 \%). Malathion treatment caused a $100 \%$ mortality of the predator ladybird 36 hours after treatment, while the lowest amount was observed in the Dayabon at $10 \mathrm{ml} \mathrm{l}^{-1}$ with $33.34 \%$ mortality.

Key words: citrus aphids; Coccinella septempunctata; mortality; botanical pesticides
Učinek biološko primernih insekticidov na uši citrusov in njihovega predatorja (Coccinella septempunctata L.)

Izvleček: Za ovrednotenje selektivne učinkovitosti posebnih pesticidov pri biološkem uravnavanju vrst je bila ovrednotena kontaktna toksičnost različnih snovi, ki so obsegale obravnavanje z $10 \mathrm{ml} \mathrm{l}^{-1}$ pomivalne tekočine, obravnavanje $\mathrm{z}$ Dayabonom v koncentracijah 5, 6, 7, 8, 9 in $10 \mathrm{ml} \mathrm{l}^{-1}$, Palizinom v koncentracijah 1,5, 2,5 in 2,5 $\mathrm{ml} \mathrm{l}^{-1}$, s Palizinom 1,5, 2 in $2,5+$ citrolnim oljem $5 \mathrm{ml} \mathrm{l}^{-1}$, Tondoxirjem 2 in $3+$ milom Bartar $1 \mathrm{ml} \mathrm{l}^{-1}$, Malathionom $2 \mathrm{ml} \mathrm{l}^{-1}$ in kontrolo (voda) na odrasle uši v najpomembenjših nasadih citrusov in na njihovega predatorja, Coccinella septempunctata L. v laboratorijskih razmerah. Rezultati so odkrili, da je povzročilo obravnavanje s Palizinom 2,5 + citrolnim oljem $5 \mathrm{ml} \mathrm{l}^{-1}$ največjo smrtnost zelene uši citrusov (Aphis spiraecola Patch, 1914) po 36 urah. Koncentracije 7 do $10 \mathrm{ml} \mathrm{l}^{-1}$ Dayabona in Palizina 2,5 + citrolnega olja $5 \mathrm{ml} \mathrm{l}^{-1}$, kot tudi $3 \mathrm{ml} \mathrm{l}^{-1}$ Tondexirja + Bartar mila $1 \mathrm{ml} \mathrm{l}^{-1}$ so imele največjo smrtnost rjavih citrusovih uši, Aphis citricidus (Kirkaldy, 1907), 36 ur po obravnavanju (100\%). Dodatno so obravnavanja s Palizinom $2 \mathrm{ml} \mathrm{l}^{-1}+$ citrolnim oljem $5 \mathrm{ml} \mathrm{l}^{-1}, 2 \mathrm{ml} \mathrm{l}^{-1}$ Tondexirja + Bartar mila $1 \mathrm{ml} \mathrm{l}^{-1}$ in Dayabona $\mathrm{v}$ koncentracija $5 \mathrm{ml} \mathrm{l}^{-1}$ in $6 \mathrm{ml} \mathrm{l}^{-1}$ povzročile enako smrtnost črne citrusove uši, Toxoptera aurantii (Boyer de Fonscolombe, 1841). Tondexir, $3 \mathrm{ml} \mathrm{l}^{-1}+$ Bartar milo, $1 \mathrm{ml} \mathrm{l}^{-1}$ sta 24 ur po ubravnavanju povzročila največjo smrtnost bombaževe uši, Aphis gossypii Glover, 1877 (83,88 \%). Obravnavanje $z$ Malathionom je povzročilo $100 \%$ smrtnost polonice 36 ur po obravnavanju, medtem, ko je bila njena najmanjša smrtnost, 33,4 \% , pri obravnavanju z Dayabonom pri $10 \mathrm{ml} \mathrm{l}^{-1}$.

Ključne besede: uši citrusov; Coccinella septempunctata; smrtnost; botanični pesticidi

1 Sari Agricultural and Natural Sciences University, Faculty of Crop Sciences, Department of Plant Protection, Sari, Iran

2 Corresponding author, e-mail: behnamamiri39@yahoo.com

3 Shahed University, Faculty of Agricultural Sciences, Department of Plant Protection, Tehran, Iran 


\section{INTRODUCTION}

Aphids are important pests of citrus growth because of direct damage, mainly on young plants, or because of virus transmission. These species are widespread and four of them, green citrus aphid, A. spiraecola Patch, cotton aphid, A. gossypii Glover, 1877, brown citrus aphid, Toxoptera citricidus (Kirkaldy, 1907) and black citrus aphid, T. aurantii (Boyer de Fonscolombe, 1841), are especially abundant (Lapchin et al., 1994). These are the most important pests of citrus trees in northern Iran (Abbasipour \& Basij, 2016). The citrus aphids are responsible for direct and indirect damages. The former is highly correlated to the aphid species and to the density of its population, as well as to the species and the age of infested citrus trees. Damage consists of leaves' deformation and a reduced development of the infested shoots; such injuries have a negative effect mostly on the growth of young trees. In addition, the aphid infestation to the flowers and the very young fruits may cause their drop. Indirect damages are caused by the excretion of the honeydew, on which, sooty mould fungi raise later. But the greatest threat of the aphid infestation on citrus is undoubtedly represented by their efficiencies as the vector of the citrus virus diseases and particularly of the "Tristeza" (Cavalloro \& Martino, 1985).

Nowadays, several groups of insecticides are being used against the main citrus pests (Tena and GarcíaMarí, 2011; Urbaneja et al., 2012). Furthermore, especially in the case of clementines (Citrus clementina Hort. ex Tan.) because of their tender flushes, citrus aphids and the two-spotted spider mite, Tetranychus urticae Koch (Acari: Tetranychidae) are considered important pests (Jacas et al., 2010; Urbaneja et al., 2012).

Ladybirds are one of the largest groups of predator insects found in many habitats, including crops, gardens, forests and other places (Ali \& Rizvi, 2010). The seven-spotted ladybird, Coccinella septempunctata L. (Col.: Coccinellidae) is one of the most common predator species of aphids. The origin of this insect is Asia and Europe and is now widely considered one of the most widely known species in the regions Nearctic, Palearctic, and Oriental (Honek \& Martinkova, 2005; Barjadze et al., 2009). This species has been reported from all regions of Iran and in various ecosystems (Ansaripour et al., 2012). Regarding the spread of aphids, limiting chemical control is necessary to reduce the amount of used pesticides and to detect and apply nonchemical methods. This can be done by introducing low-risk biological agents and pesticides with specific dosage and time.

In contrast to the destructive impacts of chemi- cal insecticides, the use of biorational pesticides seems a safe and convenient solution to control these pests. Palizin is a water-soluble wetting agent having an herbal origin and formulated as a $65 \%$ water-soluble concentrated liquid. Sirinol, peppermint, and eucalyptus extracts are used for making the compound. Dayabon, another tested compound has been formulated based on thyme essential oil (EC $10 \%$ ). Tondexir, the green, the concentrated liquid contains red pepper extract (EC $85 \%$ ). This combination, like the previous composition, acts by contact and causes the death of the pest through the respiratory system disorder (Anonymous, 2015; Imani \& Toorani, 2016).

Unfortunately, and despite the importance of predator ladybeetles, C. septempunctata in the citrus agroecosystem, there is scarce and disperse literature on the side-effects of the pesticides used in citrus on it (Suma et al., 2009; Zappalà, 2010). Thus, the aims of this study were to evaluate and compare the biorational insecticides with conventional pesticides for control of some important aphids of citrus orchards and to evaluate their impact on its main predator, C. septempunctata. This information will allow to assess the acute toxicity of biorational pesticides on citrus aphids and their predators.

\section{MATERIALS AND METHODS}

\subsection{PLANT AND APHID CULTURES}

The 'Thomson Navel' variety of orange Citrus sinensis $\mathrm{L}$. seedlings were planted in plastic pots $(20 \mathrm{~cm}$ diameter $\times 30 \mathrm{~cm}$ height) containing a 1:1 mixture of perlite: vermiculite in a greenhouse at $25 \pm 2{ }^{\circ} \mathrm{C}$ and 16L: $8 \mathrm{D}$ h photoperiods. Stock laboratory cultures of the studied aphids, including the citrus green aphid, $A$. spiraecola, the cotton aphid, A. gossypii, the brown citrus aphid, T. citricidus and the citrus black aphid, T. aurantii were established on its respective host plants from individuals that were field-collected from the same host plant in Sari city of Mazandran province, north of Iran in 2017 and were reared under the same physical conditions as the plant.

Early colonies of aphids were collected from infested citrus orchards in Sari, Iran, and transferred to the laboratory. Adult aphids were placed on citrus leaves to obtain a similar population of adults after a few days of nymphs were appeared. Then, adult aphids were separated from the leaves and the aphids were placed into the germinator. After several days and emergence 
of same-aged adult aphids, they were used for bioassay experiments.

\subsection{PREDATOR LADYBIRD REARING}

A number of the seven-spotted ladybird, C. septempunctata were collected during the winter that were fed and matured in citrus orchards. They were then transferred to the germinator at $25 \pm 2{ }^{\circ} \mathrm{C}, 65 \pm 5 \%$ $\mathrm{RH}$ and $16 \mathrm{~L}: 8 \mathrm{D}$ h photoperiods. Adults and nymphs of citrus aphids were daily used to feed the ladybirds.

\subsection{BIOASSAY TESTS}

For each treatment, ten replicates were considered, and in each replicate, 30 adult aphids were placed on leaves of the host plant in Petri dishes with a diameter of 8 and a height of 1.5 centimeters. The treatments included: 1) Aveh dishwashing liquid $\left.\left(10 \mathrm{ml} \mathrm{l}^{-1}\right), 2\right)$ Dayabon (5 $\left.\mathrm{ml} \mathrm{l}^{-1}\right)$, 3) Dayabon $\left(6 \mathrm{ml} \mathrm{l}^{-1}\right)$, 4) Dayabon $\left(7 \mathrm{ml} \mathrm{l}^{-1}\right)$,5) Dayabon $\left.\left(8 \mathrm{ml} \mathrm{l}^{-1}\right), 6\right)$ Dayabon $\left(9 \mathrm{ml} \mathrm{l}^{-1}\right)$, 7) Dayabon $\left.\left(10 \mathrm{ml} \mathrm{l}^{-1}\right), 8\right)$ Palizin $\left(1.5 \mathrm{ml} \mathrm{l}^{-1}\right)$, 9) Palizin $\left(2 \mathrm{ml} \mathrm{l}^{-1}\right)$, 10) Palizin $\left(2.5 \mathrm{ml} \mathrm{l}^{-1}\right)$, 11) Palizin $\left(1.5 \mathrm{ml} \mathrm{l}^{-1}\right)$
+ Citrol oil $\left.\left(5 \mathrm{ml} \mathrm{l}^{-1}\right), 12\right)$ Palizin $\left(2 \mathrm{ml} \mathrm{l}^{-1}\right)+$ Citrol oil $\left(5 \mathrm{ml} \mathrm{l}^{-1}\right)$, 13) Palizin $\left(2.5 \mathrm{ml} \mathrm{l}^{-1}\right)+$ Citrol oil $\left(5 \mathrm{ml} \mathrm{l}^{-1}\right)$, 14) Tondexir $2 \mathrm{ml} \mathrm{l}^{-1}+$ Bartar Soap $1 \mathrm{ml} \mathrm{l}^{-1}$, 15) Tondexir $3 \mathrm{ml} \mathrm{l}^{-1}+$ Bartar soap $1 \mathrm{ml} \mathrm{l}^{-1}$, 16) Malathion $2 \mathrm{ml}$ $\mathrm{l}^{-1}$ and 17) control (water). Then, a certain amount of each treatment was carried out with a sampler and poured into a liter of water and sprayed with a 10-milliliter (Potter precision spray tower) spray bottle (Potter Precision Spray Tower, 2000) on each leaf. Due to the fact that the capacity of the device is from a half to one milliliter, at each stage, one milliliter was sprayed on the leaf containing aphids, and this operation was repeated for 10 times, for each leaf at $10 \mathrm{ml}$ spray. All experiments were replicated three times. Petri-dish containing aphids were place in the germinator at $25 \pm 2{ }^{\circ} \mathrm{C}$, $65 \pm 5 \% \mathrm{RH}$ and $16 \mathrm{~L}: 8 \mathrm{D}$ h photoperiods. Live and dead aphids were counted and their mortality rate was estimated at 12, 24 and 36 hours after treatment. Insects that were unable to move their legs and tentacles against hot needle excitation were considered dead. In case of death in the control, the percent mortality of the treatments was corrected by Abbott's formula (Finny, 1971). These experiments were performed on each of the four-aphid species, separately in 10 replicates and 30 aphids per replicate.

Table 1: Percentage mean $( \pm$ SE) mortality of the green citrus aphid, Aphis spiraecola treated with different chemical compounds in different times

\begin{tabular}{|c|c|c|c|}
\hline \multirow[b]{2}{*}{ Treatment } & \multicolumn{3}{|c|}{ Mean $( \pm$ SE) mortality at different intervals $(\mathrm{h})$} \\
\hline & $12 \mathrm{~h}$ & $24 \mathrm{~h}$ & $36 \mathrm{~h}$ \\
\hline dishwashing liquid (Ave) $10 \mathrm{ml} \mathrm{l}^{-1}$ & $46.78 \pm 0.81^{\mathrm{ef}}$ & $50.62 \pm 0.57^{\mathrm{fg}}$ & $28.28 \pm 0.82^{\mathrm{k}}$ \\
\hline Dayabon $5 \mathrm{ml} \mathrm{l}^{-1}$ & $26.81 \pm 0.61^{\mathrm{h}}$ & $36.71 \pm 0.78^{\mathrm{i}}$ & $45.37 \pm 0.62^{\mathrm{i}}$ \\
\hline Dayabon $6 \mathrm{ml} \mathrm{l}^{-1}$ & $26.41 \pm 0.46^{\mathrm{h}}$ & $37.55 \pm 0.43^{\mathrm{hi}}$ & $41.73 \pm 0.55^{j}$ \\
\hline Dayabon $7 \mathrm{ml} \mathrm{l}^{-1}$ & $28.40 \pm 0.65^{\mathrm{h}}$ & $37.15 \pm 0.66^{\mathrm{i}}$ & $49.69 \pm 1.61^{\mathrm{h}}$ \\
\hline Dayabon $8 \mathrm{ml} \mathrm{l}^{-1}$ & $38.04 \pm 0.51^{\mathrm{g}}$ & $40.24 \pm 0.79^{\mathrm{h}}$ & $52.06 \pm 0.84^{\mathrm{h}}$ \\
\hline Dayabon $9 \mathrm{ml} \mathrm{l}^{-1}$ & $43.53 \pm 0.69^{f}$ & $53.18 \pm 0.60^{f}$ & $62.61 \pm 0.56^{\mathrm{f}}$ \\
\hline Dayabon $10 \mathrm{ml} \mathrm{l}^{-1}$ & $49.68 \pm 0.61^{\mathrm{d}}$ & $58.21 \pm 0.61^{\mathrm{f}}$ & $71.76 \pm 0.55^{\mathrm{e}}$ \\
\hline Palizin $1.5 \mathrm{ml} \mathrm{l}^{-1}$ & $28.64 \pm 0.61^{\mathrm{h}}$ & $32.88 \pm 0.85^{j}$ & $51.94 \pm 0.51^{\mathrm{h}}$ \\
\hline Palizin $2 \mathrm{ml} \mathrm{l}^{-1}$ & $38.08 \pm 0.50^{g}$ & $49.05 \pm 0.66^{\mathrm{g}}$ & $58.40 \pm 0.49^{g}$ \\
\hline Palizin $2.5 \mathrm{ml} \mathrm{l}^{-1}$ & $58.22 \pm 0.73^{c}$ & $61.76 \pm 0.67^{g}$ & $72.32 \pm 0.68^{\mathrm{e}}$ \\
\hline Palizin $1.5 \mathrm{ml} \mathrm{ll}^{-1}+$ Citrol oil $5 \mathrm{ml} \mathrm{l}^{-1}$ & $45.80 \pm 0.78^{\mathrm{ef}}$ & $50.34 \pm 0.45^{\mathrm{fg}}$ & $63.34 \pm 0.65^{f}$ \\
\hline Palizin $2 \mathrm{ml} \mathrm{l}^{-1}+$ Citrol oil $5 \mathrm{ml} \mathrm{l}^{-1}$ & $59.49 \pm 0.55^{c}$ & $67.86 \pm 0.55^{\mathrm{c}}$ & $82.18 \pm 0.47^{c}$ \\
\hline Palizin $2.5 \mathrm{ml} \mathrm{l}^{-1}+$ Citrol oil $5 \mathrm{ml} \mathrm{l}^{-1}$ & $78.89 \pm 0.49^{a}$ & $84.37 \pm 0.38^{\mathrm{a}}$ & $99.37 \pm 0.30^{\mathrm{a}}$ \\
\hline Tondexir $2 \mathrm{ml} \mathrm{l}^{-1}+$ Bar-Tar wetting agent $1 \mathrm{ml} \mathrm{l}^{-1}$ & $68.42 \pm 0.47^{b}$ & $72.30 \pm 0.55^{\mathrm{b}}$ & $77.11 \pm 0.46^{\mathrm{d}}$ \\
\hline Tondexir $3 \mathrm{ml} \mathrm{l}^{-1}+$ Bar-Tar wetting agent $1 \mathrm{ml} \mathrm{l}^{-1}$ & $76.65 \pm 0.76^{\mathrm{b}}$ & $83.49 \pm 0.48^{\mathrm{a}}$ & $95.21 \pm 0.65^{b}$ \\
\hline Malathion $2 \mathrm{ml} \mathrm{l}^{-1}$ & $58.79 \pm 0.51^{\mathrm{c}}$ & $63.44 \pm 0.60^{\mathrm{d}}$ & $39.49 \pm 1.04^{j}$ \\
\hline Control (water) & $7.57 \pm 0.38^{\mathrm{i}}$ & $7.66 \pm 0.38^{\mathrm{k}}$ & $12.21 \pm 0.43^{1}$ \\
\hline
\end{tabular}

* Means were compared by Tukey's range test at 0.05 level. The similar letters indicate no significant difference. 
The adult ladybirds, C. septempunctata were used for bioassay experiments. The method of bioassay tests for ladybird was similar to that of aphids, with the exception that 10 adult insects were used in each replication and, the number of live and dead insects were estimated at 12, 24, 36, 48 and 60 hours after treatment. The experiments were bio-assayed with 16 treatments and control with 10 replicates for each of the compounds.

\subsection{STATISTICAL ANALYSIS.}

In the case of mortality in the control, the mortality percentage of other 16 treatments was modified using the Abbott formula (Finney, 1971). The data were subjected to a two-way analysis of variance (ANOVA) and the means were compared by Tukey's range test at 0.05 level, using SPSS program (SPSS, 2006).

\section{RESULTS}

The results of bioassay experiments on the effects of different treatments of various compounds on the black citrus aphid, T. aurantii, the brown aphid, T. citri- cidus, the cotton aphid A. gossypii and the green citrus aphid, A. spiraecola, as well as the seven-spotted ladybird insects, are listed in Tables 1 to 5 .

The results of analysis of bioassay data for the green citrus aphid, A. spiraecola showed that there is a significant difference between various treatments at the test times. For a period of 12 hours ( $\mathrm{df}=16, \mathrm{~F}=$ $1000.804, p<0.001), 24$ hours $(\mathrm{df}=16, \mathrm{~F}=1048.339, p<$ 0.001 ) and for 36 hours ( $\mathrm{df}=16, \mathrm{~F}=988.059, p<0.001$ ), based on these results, the treatment Palizin 2.5+ Citroloil $5 \mathrm{ml} \mathrm{l}^{-1}$ had the highest mortality at 12, 24 and $36 \mathrm{~h}$, which was $76.89,84.37$ and $99.37 \%$, respectively.

Among Dayabon treatments, treatment of $10 \mathrm{ml} \mathrm{l}^{-1}$ had the highest mortality rate at different times, so that at 36 hours about $71.76 \%$ of aphids died. For the dishwashing liquid $10 \mathrm{ml} \mathrm{l}^{-1}$ treatment, the mortality rate increased from 12 hours to 24 hours and 36 hours. Indicating that the time of 36 hours after treatment had the highest mortality rate $(58.28 \%)$ (Table 1$)$.

According to the variance analysis results of bioassay testing of the black citrus aphid, T. aurantii, a significant difference was observed between all treatments at test times (for 12 hours, $\mathrm{df}=16, \mathrm{~F}=680.645, p<$ 0.001 ; for 24 hours, $\mathrm{df}=16, \mathrm{~F}=2605.078, p<0.001$ and for 36 hours, $\mathrm{df}=16, \mathrm{~F}=146.352, p<0.001)$. The results

Table 2: Percentage mean $( \pm \mathrm{SE})$ mortality of the black citrus aphid, Toxoptera aurantii treated with different chemical compounds in different times

\begin{tabular}{|c|c|c|c|}
\hline \multirow[b]{2}{*}{ Treatment } & \multicolumn{3}{|c|}{ Mean $( \pm$ SE) mortality at different intervals $(h)$} \\
\hline & $12 \mathrm{~h}$ & $24 \mathrm{~h}$ & $36 \mathrm{~h}$ \\
\hline dishwashing liquid (Ave) $10 \mathrm{ml} \mathrm{l}^{-1}$ & $55.57 \pm 1.0^{\mathrm{g}}$ & $95.31 \pm 0.80^{\mathrm{b}}$ & $1.08 \pm 0.37^{\mathrm{d}}$ \\
\hline Dayabon $5 \mathrm{ml} \mathrm{l}^{-1}$ & $66.72 \pm 0.68^{e}$ & $100 \pm 0.0^{\mathrm{a}}$ & $100 \pm 0.0^{\mathrm{a}}$ \\
\hline Dayabon $6 \mathrm{ml} \mathrm{l}^{-1}$ & $75.04 \pm 0.70^{\mathrm{d}}$ & $100 \pm 0.0^{\mathrm{a}}$ & $100 \pm 0.0^{\mathrm{a}}$ \\
\hline Dayabon $7 \mathrm{ml} \mathrm{l}^{-1}$ & $92.09 \pm 0.72^{\mathrm{bc}}$ & $100 \pm 0.0^{\mathrm{a}}$ & $100 \pm 0.0^{\mathrm{a}}$ \\
\hline Dayabon $8 \mathrm{ml} \mathrm{l}^{-1}$ & $96.68 \pm 0.99^{\mathrm{ab}}$ & $100 \pm 0.0^{\mathrm{a}}$ & $100 \pm 0.0^{\mathrm{a}}$ \\
\hline Dayabon $9 \mathrm{ml} \mathrm{l}^{-1}$ & $100 \pm 0.0^{\mathrm{a}}$ & $100 \pm 0.0^{\mathrm{a}}$ & $100 \pm 0.0^{\mathrm{a}}$ \\
\hline Dayabon $10 \mathrm{ml} \mathrm{l}^{-1}$ & $100 \pm 0.0^{\mathrm{a}}$ & $100 \pm 0.0^{\mathrm{a}}$ & $100 \pm 0.0^{\mathrm{a}}$ \\
\hline Palizin $1.5 \mathrm{ml} \mathrm{l}^{-1}$ & $31.70 \pm 0.70^{\mathrm{i}}$ & $39.15 \pm 0.61^{g}$ & $48.32 \pm 0.51^{\mathrm{c}}$ \\
\hline Palizin $2 \mathrm{ml} \mathrm{l}^{-1}$ & $41.44 \pm 0.50^{\mathrm{h}}$ & $52.39 \pm 0.72^{\mathrm{f}}$ & $76.38 \pm 0.65^{\mathrm{b}}$ \\
\hline Palizin $2.5 \mathrm{ml} \mathrm{l}^{-1}$ & $61.52 \pm 0.62^{f}$ & $73.35 \pm 0.69^{d}$ & $84.19 \pm 0.93^{\mathrm{b}}$ \\
\hline Palizin $1.5 \mathrm{ml} \mathrm{l}^{-1}+$ Citrol oil $5 \mathrm{ml} \mathrm{l}^{-1}$ & $55.61 \pm 0.92^{\mathrm{g}}$ & $64.88 \pm 0.69^{\mathrm{e}}$ & $77.50 \pm 0.81^{\mathrm{b}}$ \\
\hline Palizin $2 \mathrm{ml} \mathrm{l}^{-1}+$ Citrol oil $5 \mathrm{ml} \mathrm{l}^{-1}$ & $90.80 \pm 0.81^{c}$ & $98.29 \pm 0.54^{c}$ & $100 \pm 0.0^{\mathrm{a}}$ \\
\hline Palizin $2.5 \mathrm{ml} \mathrm{l}^{-1}+$ Citrol oil $5 \mathrm{ml} \mathrm{l}^{-1}$ & $98.38 \pm 0.62^{\mathrm{a}}$ & $100 \pm 0.0^{\mathrm{a}}$ & $100 \pm 0.0^{\mathrm{a}}$ \\
\hline Tondexir $2 \mathrm{ml} \mathrm{l}^{-1}+$ Bar-Tar wetting agent $1 \mathrm{ml} \mathrm{l}^{-1}$ & $90.13 \pm 0.78^{c}$ & $88.16 \pm 0.89^{c}$ & $100 \pm 0.0^{\mathrm{a}}$ \\
\hline Tondexir $3 \mathrm{ml} \mathrm{l}^{-1}+$ Bar-Tar wetting agent $1 \mathrm{ml} \mathrm{l}^{-1}$ & $100 \pm 0.0^{\mathrm{a}}$ & $100 \pm 0.0^{\mathrm{a}}$ & $100 \pm 0.0^{\mathrm{a}}$ \\
\hline Malathion $2 \mathrm{ml} \mathrm{l}^{-1}$ & $73.64 \pm 3.28^{\mathrm{d}}$ & $98.11 \pm 0.70^{\mathrm{d}}$ & $39.49 \pm 1.64^{\mathrm{b}}$ \\
\hline Control (water) & $11.14 \pm 0.62^{j}$ & $10.64 \pm 0.78^{\mathrm{h}}$ & $11.02 \pm 0.79^{\mathrm{d}}$ \\
\hline
\end{tabular}

${ }^{*}$ Means were compared by Tukey's range test at 0.05 level. The similar letters indicate no significant difference. 
Table 3: Percentage mean $( \pm \mathrm{SE})$ mortality of the brown citrus aphid, Aphis citricidus treated with different chemical compounds in different times

\begin{tabular}{|c|c|c|c|}
\hline \multirow[b]{2}{*}{ Treatment } & \multicolumn{3}{|c|}{ Mean $( \pm$ SE) mortality at different intervals $(\mathrm{h})$} \\
\hline & $12 \mathrm{~h}$ & $24 \mathrm{~h}$ & $36 \mathrm{~h}$ \\
\hline dishwashing liquid (Ave) $10 \mathrm{ml} \mathrm{l}^{-1}$ & $41.84 \pm 1.04^{\mathrm{h}}$ & $82.65 \pm 0.90^{c}$ & $32.05 \pm 0.98^{\mathrm{h}}$ \\
\hline Dayabon $5 \mathrm{ml} \mathrm{l}^{-1}$ & $47.0 \pm 0.85^{\mathrm{g}}$ & $67.61 \pm 0.84^{\mathrm{de}}$ & $72.38 \pm 0.55^{\mathrm{d}}$ \\
\hline Dayabon $6 \mathrm{ml} \mathrm{l}^{-1}$ & $54.61 \pm 0.87^{\mathrm{f}}$ & $70.53 \pm 0.93^{\mathrm{d}}$ & $81.34 \pm 0.72^{c}$ \\
\hline Dayabon $7 \mathrm{ml} \mathrm{l}^{-1}$ & $84.20 \pm 0.59^{\mathrm{d}}$ & $96.89 \pm 1.08^{\mathrm{ab}}$ & $100 \pm 0.0^{\mathrm{a}}$ \\
\hline Dayabon $8 \mathrm{ml} \mathrm{l}^{-1}$ & $91.96 \pm 0.48^{\mathrm{c}}$ & $96.55 \pm 1.28^{\mathrm{ab}}$ & $100 \pm 0.0^{\mathrm{a}}$ \\
\hline Dayabon $9 \mathrm{ml} \mathrm{l}^{-1}$ & $96.26 \pm 0.53^{\mathrm{b}}$ & $100 \pm 0.0^{\mathrm{a}}$ & $100 \pm 0.0^{\mathrm{a}}$ \\
\hline Dayabon $10 \mathrm{ml} \mathrm{l}^{-1}$ & $100 \pm 0.0^{\mathrm{a}}$ & $100 \pm 0.0^{\mathrm{a}}$ & $100 \pm 0.0^{\mathrm{a}}$ \\
\hline Palizin $1.5 \mathrm{ml} \mathrm{l}^{-1}$ & $25.83 \pm 0.68^{\mathrm{i}}$ & $37.66 \pm 0.58^{\mathrm{h}}$ & $41.95 \pm 1.08^{\mathrm{g}}$ \\
\hline Palizin $2 \mathrm{ml} \mathrm{l}^{-1}$ & $34.35 \pm 0.66^{\mathrm{i}}$ & $40.73 \pm 0.71^{\mathrm{h}}$ & $42.83 \pm 0.72^{g}$ \\
\hline Palizin $2.5 \mathrm{ml} \mathrm{l}^{-1}$ & $44.29 \pm 0.76^{\mathrm{gh}}$ & $48.22 \pm 0.77^{g}$ & $52.60 \pm 0.70^{f}$ \\
\hline Palizin $1.5 \mathrm{ml} \mathrm{l}^{-1}+$ Citrol oil $5 \mathrm{ml} \mathrm{l}^{-1}$ & $40.90 \pm 0.70^{\mathrm{h}}$ & $54.75 \pm 0.72^{\mathrm{f}}$ & $63.91 \pm 0.67^{\mathrm{e}}$ \\
\hline Palizin $2 \mathrm{ml} \mathrm{l}^{-1}+$ Citrol oil $5 \mathrm{ml} \mathrm{l}^{-1}$ & $55.67 \pm 0.75^{\mathrm{f}}$ & $65.56 \pm 0.82^{\mathrm{e}}$ & $85.48 \pm 0.81^{\mathrm{b}}$ \\
\hline Palizin $2.5 \mathrm{ml} \mathrm{l}^{-1}+$ Citrol oil $5 \mathrm{ml} \mathrm{l}^{-1}$ & $73.91 \pm 0.65^{j}$ & $95.84 \pm 0.86^{\mathrm{b}}$ & $100 \pm 0.0^{\mathrm{a}}$ \\
\hline Tondexir $2 \mathrm{ml} \mathrm{l}^{-1}+$ Bar-Tar wetting agent $1 \mathrm{ml} \mathrm{l}^{-1}$ & $70.99 \pm 0.87^{\mathrm{e}}$ & $82.56 \pm 0.64^{c}$ & $85.69 \pm 0.88^{b}$ \\
\hline Tondexir $3 \mathrm{ml} \mathrm{l}^{-1}+$ Bar-Tar wetting agent $1 \mathrm{ml} \mathrm{l}^{-1}$ & $85.13 \pm 1.24^{\mathrm{d}}$ & $98.54 \pm 0.81^{\mathrm{ab}}$ & $100 \pm 0.0^{\mathrm{a}}$ \\
\hline Malathion $2 \mathrm{ml} \mathrm{l}^{-1}$ & $54.73 \pm 0.75^{\mathrm{f}}$ & $83.67 \pm 0.77^{c}$ & $62.78 \pm 0.77^{\mathrm{e}}$ \\
\hline Control (water) & $7.95 \pm 0.47^{\mathrm{k}}$ & $8.73 \pm 0.57^{\mathrm{i}}$ & $9.24 \pm 0.56^{\mathrm{i}}$ \\
\hline
\end{tabular}

* Means were compared by Tukey's range test at 0.05 level. The similar letters indicate no significant difference.

of the mean comparison indicated that the treatments of Dayabon 9 and $10 \mathrm{ml} \mathrm{l}^{-1}$, as well as Tondexir + Bartar soap $3+1 \mathrm{ml} \mathrm{l}^{-1}$ had the highest effect in 12 hours after the treatment and resulted in the mortality of $100 \%$ of the black citrus aphids. In 36 hours after treatment, all concentrations of Dayabon, Tondexir + Bartar soap, Dishwashing liquid (Ave) $10 \mathrm{ml} \mathrm{l}^{-1}$ and Palizin 2, 2.5 + citrol oil $5 \mathrm{ml} \mathrm{l}^{-1}$ treatments caused $100 \%$ of aphid mortality. While the lowest mortality rate was recorded for control (11.92\%) (Table 2).

The results of the variance analysis of bioassay data from the brown citrus aphid, T. citricidus showed a significant difference between the treatments at different time of testing. At 12 hours $(\mathrm{df}=16, \mathrm{~F}=1255.853$, $p<0.001), 24$ hours ( $\mathrm{df}=16, \mathrm{~F}=1160.900,<0.001)$ and 36 hours $(\mathrm{df}=16, \mathrm{~F}=2046.868, p<0.001)$ post treatments. The results of the mean comparison showed that when Palizin insecticide was combined with citrol oil, its efficiency was increased. At 36 hours after treatment, the concentrations of Palizin 0.5, 2 and $2.5 \mathrm{ml} \mathrm{l}^{-1}$, caused $41.95,42.83$ and $52.60 \%$ mortality, respectively, but when there were combined with citrol oil, mortality increased to $63.91,85.48$ and $100 \%$, respectively. In the treatment of Malathion, over a period of 12 hours after treatment to 24 and 36 hours, the mortality rate increased from 54.73 to $83.67 \%$ and $92.78 \%$ mortality, respectively (Table 3 ).

The results of the variance analysis of bioassay tests in different treatments on the cotton aphid, $A$. gossypii showed that there was a significant difference between treatments at 12,24 and 36 hours. At $12 \mathrm{~h}$ (df $=16, \mathrm{~F}=871.371, p<0.001), 24$ hours $(\mathrm{df}=16, \mathrm{~F}=$ $844.016, p<0.001)$ and 36 hours $(\mathrm{df}=16, \mathrm{~F}=322.346$, $p<0.001)$. Regarding the results of the mean comparison at 12 hours after the treatment, the highest mortality rates occurred in Tondexir $3+$ Bartar soap $1 \mathrm{ml} \mathrm{l}^{-1}$ and Malathion $2 \mathrm{ml} \mathrm{l}^{-1}$ treatments, which was 75.40 and $74.32 \%$, respectively. In the 24 hours after treatment, as in 12 hours, the two treatments with 83.89 and $82.73 \%$ mortality. But 36 hours after treatment, Tondexir $3 \mathrm{ml}$ $1^{-1}+$ soap Bartar $1 \mathrm{ml}^{-1}$ treatment alone was found in the first group with $88.73 \%$ of mortality. Meanwhile, Malathion $2 \mathrm{ml} \mathrm{l}^{-1}$ was placed in the second group (b) (Table 4).

Based on results of the variance analysis of data from bioassay tests of different treatments on the seven-spotted ladybird, C. septempunctata at different times after treatment showed a significant difference among treatments at 12 to 60 hours after treatment. For 12 hours ( $\mathrm{df}=16, \mathrm{~F}=47.631, p<0.001)$, for 24 hours 
Table 4: Percentage mean $( \pm$ SE) mortality of the citrus aphid, Aphis gossypii treated with different chemical compounds in different times

\begin{tabular}{|c|c|c|c|}
\hline \multirow[b]{2}{*}{ Treatment } & \multicolumn{3}{|c|}{ Mean $( \pm$ SE) mortality at different intervals $(\mathrm{h})$} \\
\hline & $12 \mathrm{~h}$ & $24 \mathrm{~h}$ & $36 \mathrm{~h}$ \\
\hline dishwashing liquid (Ave) $10 \mathrm{ml} \mathrm{l}^{-1}$ & $50.34 \pm 0.68^{\mathrm{ef}}$ & $53.47 \pm 0.79^{f}$ & $62.44 \pm 0.91^{\mathrm{d}}$ \\
\hline Dayabon $5 \mathrm{ml} \mathrm{l}^{-1}$ & $29.56 \pm 0.66^{\mathrm{h}}$ & $34.28 \pm 0.81^{\mathrm{gh}}$ & $34.94 \pm 0.48^{\mathrm{f}}$ \\
\hline Dayabon $6 \mathrm{ml} \mathrm{l}^{-1}$ & $35.81 \pm 0.75^{\mathrm{h}}$ & $36.02 \pm 0.57^{g}$ & $42.33 \pm 0.65^{\mathrm{e}}$ \\
\hline Dayabon $7 \mathrm{ml} \mathrm{l}^{-1}$ & $44.22 \pm 0.72^{\mathrm{h}}$ & $57.93 \pm 0.56^{\mathrm{e}}$ & $63.45 \pm 1.75^{\mathrm{d}}$ \\
\hline Dayabon $8 \mathrm{ml} \mathrm{l}^{-1}$ & $55.53 \pm 0.73^{\mathrm{g}}$ & $62.68 \pm 0.61^{\mathrm{d}}$ & $70.27 \pm 0.55^{\mathrm{bc}}$ \\
\hline Dayabon $9 \mathrm{ml} \mathrm{l}^{-1}$ & $54.98 \pm 0.78^{\mathrm{f}}$ & $62.78 \pm 0.87^{\mathrm{cd}}$ & $70.53 \pm 0.98^{\mathrm{bc}}$ \\
\hline Dayabon $10 \mathrm{ml} \mathrm{l}^{-1}$ & $58.34 \pm 0.82^{\mathrm{d}}$ & $68.65 \pm 0.49^{\mathrm{b}}$ & $74.84 \pm 0.79^{\mathrm{ab}}$ \\
\hline Palizin $1.5 \mathrm{ml} \mathrm{l}^{-1}$ & $9.57 \pm 0.58^{\mathrm{h}}$ & $13.02 \pm 0.65^{j}$ & $25.81 \pm 0.92^{\mathrm{g}}$ \\
\hline Palizin $2 \mathrm{ml} \mathrm{l}^{-1}$ & $12.40 \pm 0.54^{\mathrm{g}}$ & $22.30 \pm 0.76^{\mathrm{i}}$ & $26.70 \pm 2.38^{g}$ \\
\hline Palizin $2.5 \mathrm{ml} \mathrm{l}^{-1}$ & $21.56 \pm 1.03^{c}$ & $31.37 \pm 0.65^{\mathrm{h}}$ & $36.48 \pm 0.61^{\mathrm{ef}}$ \\
\hline Palizin $1.5 \mathrm{ml} \mathrm{l}^{-1}+$ Citrol oil $5 \mathrm{ml} \mathrm{l}^{-1}$ & $42.89 \pm 0.79^{\mathrm{ef}}$ & $55.0 \pm 0.93^{\mathrm{ef}}$ & $66.37 \pm 2.24^{\mathrm{cd}}$ \\
\hline Palizin $2 \mathrm{ml} \mathrm{l}^{-1}+$ Citrol oil $5 \mathrm{ml} \mathrm{l}^{-1}$ & $54.52 \pm 0.81^{c}$ & $65.15 \pm 0.91^{\mathrm{bcd}}$ & $75.03 \pm 1.0^{\mathrm{ab}}$ \\
\hline Palizin $2.5 \mathrm{ml} \mathrm{l}^{-1}+$ Citrol oil $5 \mathrm{ml} \mathrm{l}^{-1}$ & $55.45 \pm 0.80^{\mathrm{a}}$ & $66.63 \pm 1.0^{\mathrm{bc}}$ & $75.23 \pm 0.72^{\mathrm{ab}}$ \\
\hline Tondexir $2 \mathrm{ml} \mathrm{l}^{-1}+$ Bar-Tar wetting agent $1 \mathrm{ml} \mathrm{l}^{-1}$ & $61.95 \pm 0.68^{\mathrm{b}}$ & $62.07 \pm 0.83^{\mathrm{d}}$ & $63.37 \pm 0.73^{b}$ \\
\hline Tondexir $3 \mathrm{ml} \mathrm{l}^{-1}+$ Bar-Tar wetting agent $1 \mathrm{ml} \mathrm{l}^{-1}$ & $75.40 \pm 0.80^{\mathrm{b}}$ & $83.89 \pm 0.89^{\mathrm{a}}$ & $78.73 \pm 0.24^{\mathrm{a}}$ \\
\hline Malathion $2 \mathrm{ml} \mathrm{l}^{-1}$ & $74.32 \pm 0.73^{c}$ & $82.73 \pm 0.88^{\mathrm{a}}$ & $62.78 \pm 0.55^{\mathrm{bc}}$ \\
\hline Control (water) & $8.36 \pm 0.85^{\mathrm{i}}$ & $8.60 \pm 0.90^{\mathrm{k}}$ & $11.81 \pm 0.72^{\mathrm{h}}$ \\
\hline
\end{tabular}

* Means were compared by Tukey's range test at 0.05 level. The similar letters indicate no significant difference

$(\mathrm{df}=16, \mathrm{~F}=84.149, p<0.001)$, for 36 hours $(\mathrm{df}=16, \mathrm{~F}$ $=124.517,<0.001)$, for 48 hours $(\mathrm{df}=16, \mathrm{~F}=102.704$, $p<0.001)$ and for 60 hours $(\mathrm{df}=16, \mathrm{~F}=188.976, p<$ $0.001)$. According to the results presented in Table 5, the highest mortality rate of C. septempunctata ladybird were occurred at 12, 24, 36, 48 and 60 hours after treatment, by Malathion $2 \mathrm{ml} \mathrm{l}^{-1}$, which was equal to 69,92 , 100,100 and $100 \%$, respectively. While among other treatments at different times after treatment, the highest mortality rate was related to the Dayabon $10 \mathrm{ml} \mathrm{l}^{-1}$ treatment, 36 hours after treatment $35.20 \%$ (Table 5).

\section{DISCUSSION}

Knowledge of the use of selective insecticides for the pests and their natural enemies is very important in the integrated pest management. Especially when these compounds are used as pest control tools (Sterk et al., 2003). Previous studies using the above treatments showed that the highest mortality rate of the green citrus aphid, A. spiraecola was observed for Tondexir with a concentration of $3 \mathrm{ml} \mathrm{l}^{-1}+$ Bartar soaps $1 \mathrm{ml}$ $\mathrm{l}^{-1}(58 \%)$ and the lowest rate after control treatment (6\%), was produced by Palizin 1.5 and $2 \mathrm{ml} \mathrm{l}^{-1}$ (16 and
$18 \%$ ) treatments, respectively (Imani \&Toorani, 2016). In this experiment, the treatments of Tondexir 3+ Bartar soap $1 \mathrm{ml} \mathrm{l}^{-1}$ and Palizin with $1.5 \mathrm{ml}$ and $2 \mathrm{ml} \mathrm{l}^{-1}$ of after 24 hours of the treatments, had the mortality of $83.49,32.88$ and $49.05 \%$, respectively on the green citrus aphid. In addition, the treatment Palizin $2.5 \mathrm{ml}$ $\mathrm{l}^{-1}+$ citrol oil $5 \mathrm{ml} \mathrm{l}^{-1}$ had the highest mortality rate in 24 hours after treatment (84.37\%), which indicates that with increasing concentration, the efficiency of this compound has increased, as well as citrol oil $5 \mathrm{ml} \mathrm{l}^{-1}$ has a synergistic role and increases the palizin function.

Moreover,the experiments carried out on the black citrus aphid, T. aurantii in our case revealed that all Dayabon treatments, Palizin 2.5+ citrol oil $5 \mathrm{ml} \mathrm{l}^{-1}$ and Tondexir $3+$ Bartar soap $1 \mathrm{ml} \mathrm{l}^{-1}$ treatments caused $100 \%$ mortality, 24 hours after treatment (Table 2). Similar to our research, in the experiment on the black citrus aphid, T. aurantii, all concentrations of Dayabon had the highest mortality rates (100 \%) (Toorani et al., 2016).

Similarly, the highest mortality rate of the Australian mealybug, Icerya purchasi Maskell, 1878 was observed by Heydariet al. (2016c) for Dayabon treatments with concentrations of 9 and $10 \mathrm{ml} \mathrm{l}^{-1}$ and Tondexir 
Table 5: Percentage mean $( \pm \mathrm{SE})$ mortality of the seven-spot ladybird, Coccinella septempunctata, treated with different chemical compounds, in different times

\begin{tabular}{|c|c|c|c|c|c|}
\hline \multirow[b]{2}{*}{ Treatment } & \multicolumn{5}{|c|}{ Percentage mean $( \pm$ SE) mortality at different intervals $(\mathrm{h})$} \\
\hline & $12 \mathrm{~h}$ & $24 \mathrm{~h}$ & $36 \mathrm{~h}$ & $48 \mathrm{~h}$ & $60 \mathrm{~h}$ \\
\hline dishwashing liquid (Ave) $10 \mathrm{ml} \mathrm{l}^{-1}$ & $6.0 \pm 1.63^{\mathrm{def}}$ & $17.60 \pm 2.44^{\mathrm{defg}}$ & $21.0 \pm 1.34^{\text {cde }}$ & $9.17 \pm 2.13^{\text {bcdef }}$ & $0.0 \pm 0.0^{c}$ \\
\hline Dayabon $5 \mathrm{ml} \mathrm{l}^{-1}$ & $4.0 \pm 1.63^{\mathrm{f}}$ & $10.11 \pm 2.11^{\text {fghi }}$ & $8.10 \pm 1.77^{\mathrm{gh}}$ & $7.45 \pm 1.87^{\text {bcdef }}$ & $5.0 \pm 2.7^{\mathrm{ab}}$ \\
\hline Dayabon $6 \mathrm{ml} \mathrm{l}^{-1}$ & $13.0 \pm 1.53^{\text {bcdef }}$ & $17.40 \pm 1.37^{\text {defg }}$ & $10.0 \pm 1.51^{\mathrm{fgh}}$ & $3.30 \pm 1.55^{\mathrm{f}}$ & $1.30 \pm 0.0^{c}$ \\
\hline Dayabon $7 \mathrm{ml} \mathrm{l}^{-1}$ & $20.0 \pm 2.98^{\mathrm{b}}$ & $15.20 \pm 1.02^{\mathrm{efgh}}$ & $15.80 \pm 2.14^{\text {cde }}$ & $7.10 \pm 1.86^{\text {cdef }}$ & $5.70 \pm 2.7^{\mathrm{ab}}$ \\
\hline Dayabon $8 \mathrm{ml} \mathrm{l}^{-1}$ & $17.0 \pm 1.53^{\mathrm{bc}}$ & $27.49 \pm 2.48^{\mathrm{bcd}}$ & $21.20 \pm 2.09^{\mathrm{bcd}}$ & $16.0 \pm 3.20^{\mathrm{bcd}}$ & $3.80 \pm 2.3^{\mathrm{ab}}$ \\
\hline Dayabon $9 \mathrm{ml} \mathrm{l}^{-1}$ & $18.0 \pm 2.0^{\mathrm{bc}}$ & $23.70 \pm 1.98^{\text {bcde }}$ & $26.0 \pm 1.59^{\mathrm{bcd}}$ & $16.90 \pm 1.54^{\mathrm{bc}}$ & $2.70 \pm 1.0^{c}$ \\
\hline Dayabon $10 \mathrm{ml} \mathrm{l}^{-1}$ & $18.0 \pm 2.94^{\mathrm{bc}}$ & $30.80 \pm 1.06^{\mathrm{b}}$ & $33.40 \pm 1.52^{\mathrm{b}}$ & $14.50 \pm 2.79^{\mathrm{bcde}}$ & $5.20 \pm 1.0^{\mathrm{ab}}$ \\
\hline Palizin $1.5 \mathrm{ml} \mathrm{l}^{-1}$ & $4.0 \pm 1.63^{f}$ & $7.50 \pm 1.61^{\text {ghi }}$ & $6.30 \pm 1.78^{\mathrm{h}}$ & $3.60 \pm 1.38^{\mathrm{ef}}$ & $1.0 \pm 1.0^{c}$ \\
\hline Palizin $2 \mathrm{ml} \mathrm{l}^{-1}$ & $6.0 \pm 1.63^{\mathrm{def}}$ & $6.20 \pm 1.81^{\mathrm{hi}}$ & $7.20 \pm 1.32^{\mathrm{h}}$ & $5.20 \pm 1.90^{\mathrm{def}}$ & $4.30 \pm 1.0^{\mathrm{ab}}$ \\
\hline Palizin $2.5 \mathrm{ml} \mathrm{l}^{-1}$ & $5.0 \pm 2.24^{\mathrm{ef}}$ & $8.80 \pm 1.23^{\mathrm{fghi}}$ & $8.60 \pm 2.43^{\mathrm{gh}}$ & $4.10 \pm 1.73^{\mathrm{ef}}$ & $2.60 \pm 1.0^{c}$ \\
\hline Palizin $1.5 \mathrm{ml} \mathrm{l}^{-1}+$ Citrol oil $5 \mathrm{ml} \mathrm{l}^{-1}$ & $9.0 \pm 1.79^{\text {cdef }}$ & $13.20 \pm 2.12^{\text {efghi }}$ & $9.90 \pm 2.04^{\mathrm{gh}}$ & $13.20 \pm 2.33^{\text {bcdef }}$ & $7.90 \pm 2.7^{\mathrm{ab}}$ \\
\hline Palizin $2 \mathrm{ml} \mathrm{l}^{-1}+$ Citrol oil $5 \mathrm{ml} \mathrm{l}^{-1}$ & $15.0 \pm 1.67^{\mathrm{bcde}}$ & $15.70 \pm 1.38^{\text {efgh }}$ & $19.70 \pm 2.34^{\mathrm{def}}$ & $6.60 \pm 2.42^{\text {cdef }}$ & $2.0 \pm 1.0^{c}$ \\
\hline Palizin $2.5 \mathrm{ml} \mathrm{l}^{-1}+$ Citrol oil $5 \mathrm{ml} \mathrm{l}^{-1}$ & $22.0 \pm 2.91^{\mathrm{b}}$ & $11.50 \pm 2.88^{\text {fghi }}$ & $17.80 \pm 2.52^{\mathrm{defg}}$ & $11.40 \pm 2.75^{\text {bcdef }}$ & $4.60 \pm 1.3^{\mathrm{ab}}$ \\
\hline Tondexir $2 \mathrm{ml} \mathrm{l}^{-1}+$ Bar-Tar wetting agent $1 \mathrm{ml} \mathrm{l}^{-1}$ & $16.0 \pm 2.21^{\mathrm{bcd}}$ & $19.30 \pm 3.28^{\text {cdef }}$ & $25.0 \pm 2.07^{\mathrm{bcde}}$ & $2.90 \pm 1.97^{\mathrm{f}}$ & $3.30 \pm 2.7^{\mathrm{ab}}$ \\
\hline Tondexir $3 \mathrm{ml} \mathrm{l}^{-1}+$ Bar-Tar wetting agent $1 \mathrm{ml} \mathrm{l}^{-1}$ & $20.0 \pm 2.98^{b}$ & $28.60 \pm 2.98^{\mathrm{bc}}$ & $29.70 \pm 3.25^{\mathrm{bcd}}$ & $18.70 \pm 3.98^{b}$ & $11.60 \pm 2.0^{\mathrm{b}}$ \\
\hline Malathion $2 \mathrm{ml} \mathrm{l}^{-1}$ & $69.0 \pm 3.48^{\mathrm{a}}$ & $92.0 \pm 3.51^{\mathrm{a}}$ & $100 \pm 0.0^{\mathrm{a}}$ & $100 \pm 0.0^{\mathrm{a}}$ & $100 \pm 0.0^{\mathrm{a}}$ \\
\hline Control (water) & $4.0 \pm 1.63^{\mathrm{f}}$ & $4.20 \pm 1.72^{\mathrm{i}}$ & $6.50 \pm 1.78^{\mathrm{h}}$ & $5.50 \pm 1.84^{\mathrm{def}}$ & $40.80 \pm 1.0^{\mathrm{ab}}$ \\
\hline
\end{tabular}

* Means were compared by Tukey's range test at 0.05 level. The similar letters indicate no significant difference.

with concentrations of 2 and $3+$ Bartar Soap of $1 \mathrm{ml}$ $1^{-1}$ with 93, 99.33, 95 and $100 \%$ mortality, respectively.

Based on studies conducted in laboratory conditions, the $\mathrm{LC}_{50}$ values of the two extracts of red pepper, Capsicum annum L., and garlic extract on A. gossypii were 135.74 and $140.69 \mathrm{ppm}$, respectively. The result has shown the higher efficiency of pepper extracts (Kazem \& El-shereif, 2010). The use of coconut oil soap (Palizin) with concentrations of 1500 and $2500 \mathrm{ppm}$ in Iranian cucumber greenhouses reduced the population of A. gossypii aphid by 75.9 and $90.6 \%$ mortality (Baniameri, 2008). In this research, Palizin $2.5 \mathrm{ml} \mathrm{l}^{-1}$ iter + Citrol oil $5 \mathrm{ml} \mathrm{l}^{-1}$ and Tondexir $3 \mathrm{ml} \mathrm{l}^{-1}+$ Bartar soap $1 \mathrm{ml} \mathrm{l}^{-1}$ have high efficacy in reducing the population of aphids and cause a high mortality rate, as the impaction of the pest to these compounds causes gas exchange and metabolism problems, as well as the destruction of the cuticle, and finally causes the death of insects (Baniameri, 2008).

In the present study, Tondexir 2+Bartar soap $1 \mathrm{ml} \mathrm{l}^{-1}$ and Palizin $2+$ citrol oil $5 \mathrm{ml} \mathrm{l}^{-1}$, causing 72.30 and $67.86 \%$ mortality of the green citrus aphid, $A$. spiraecola (Table 1); 98.16 and $98.29 \%$ of the black citrus aphid, T. aurantii (Table 2); 82.56 and $65.56 \%$ of the brown citrus aphid, A. citricidus (Table 3 ) and 62.07 and $65.15 \%$ of the cotton aphid, A. gossypii, (Table 4) respectively. Whereas, the results of the mortality of larvae of citrus leaf miner, $P$. citrella showed that Tondexir, Sirinol, Palizin, 2000 ppm + mineral oil 5000 ppm and Spinosad $750 \mathrm{ppm}+$ mineral oil $5000 \mathrm{ppm}$, produced $31.75,45,35.75$ and $76 \%$ mortality, respectively after 24 hours (Amiri-Besheli, 2009). It seems that the aphids tested in the present research are much less resistant than citrus leaf miner larvae. The reason for that is due to Palizin and Tondexir agents which had a contact effect. For the larvae of the citrus leaf miner, they were inside leaf tissue and were relatively protected by leaf tissue, so that the tested insecticides had less contact with the larvae, and lower mortality rates were observed. Also, the highest mortality rate of the oleander yellow aphid, A. nerii Fonscolombe, 1841, was occurred in the treatments of Tondxir $3+$ Bartar soap $1 \mathrm{ml} \mathrm{l}^{-1}$ (94.46\%), Dayabon $10 \mathrm{ml} \mathrm{l}^{-1}(89.70 \%)$ and acetamipride $(90.17 \%)$, and no significant difference was observed among the three treatments (Heydari et al., 2016a). The difference in the mortality rate of the treatments used in the present study with the mentioned research can be attributed to the difference in aphid species, because the resistance of each pest is different to the insecticides comparatively to other species. 
Our results showed that almost in most tests, Palizin 1.5 and $2 \mathrm{ml} \mathrm{l}^{-1}$ treatments had a significantly lower effect than other treatments (Table 2, 3 and 4). But when these treatments were combined with citrol oil of $5 \mathrm{ml} \mathrm{l}^{-1}$, their mortality increased dramatically. But, it can be concluded that the mortality rate of the similar treatments in the present study was much higher than Imani \& Toorani (2016) research. The reason for this difference is due to the difference in the test conditions in the two studies. For example, tested aphids in the previous research were directly collected from citrus gardens and treatments were applied, whereas, in the present study, the aphids were reared for a generation in the laboratory and then were tested. This suggests that the method of insect rearing and the surrounding environmental conditions and the feeding type of an insect can effect on its resistance to insecticides.

In the present study, new botanical pesticides such as Dayabon, Palizin and Tondexir had a very little effect on the seven-spotted ladybird (Table 5). In previous studies, garlic extract (Sirinol) with a concentration of 2500 ppm has a lesser impact on natural enemies such as predator ladybirds and pistachio parasitoid in comparison with the Mospilan and Consult insecticides (Kabiri et al., 2012). In the present study, similar to the above-mentioned research, Tondexir $3+$ Bartar soap $1 \mathrm{ml} \mathrm{l}^{-1}$, containing garlic and pepper extract, had a lower effect on the seven-spotted ladybird than the chemical pesticides, malathion, caused 29.70 and $100 \%$ mortality on ladybird at 36 hours after treatment, respectively (Table 5).

Previous researches, as in our case, showed that the botanical pesticides used in the present study had a great impact on pest infestation, but had little effect on the natural enemy. For example, the results of Heydari et al. (2016b) showed that the highest percentage of mortality in the nymphs of citrus cushion, Pulvinaria aurantii Cockerell, 1896 (100\%) was occurred in the Dayabon treatment of 9 and $10 \mathrm{ml} \mathrm{l}^{-1}$, and the lowest (except for control) (34\%) was observed in Palizin $1.5 \mathrm{ml} \mathrm{l}^{-1}$. In the case of the predator ladybird, Cryptolaemus montrouzieri Mulsant, 1850 the highest and lowest mortality rates were observed in Dorsban $2 \mathrm{ml} \mathrm{l}^{-1}$ (76.66 \%) and Dayabon $5 \mathrm{ml} \mathrm{l}^{-1}$, Palizin $2 \mathrm{ml} \mathrm{l}^{-1}$ (3.33) treatments. In addition, in a research carried out in field conditions with the same treatments, it showed that Dayabon 9 and $10 \mathrm{ml} \mathrm{l}^{-1}$ treatments, in addition to controlling the citrus cushion, $P$. aurantii and not having an adverse effect on its predator, can be a suitable substitute for other high risk chemical insecticides (Tooraniet al., 2017). Furthermore, Kabiri et al. (2012) showed that three pesticides, Sirinol, Palizin and Tondexir had very low toxicity on the ladybird, Oenopia conglobate
(Linaeus, 1758), one of the most important predators of the pistachio psylla, Agonoscena pistaciae Burckhardt \& Lauterer, 1989, and were classified into a group of harmless insecticides for this predator. Due to the fact that the botanical pesticides used in this study have a direct contact effect and, by closing the respiratory tract of the skin, cause mortality of the pests, therefore, there is less effect on the mortality of C. septempunctata ladybird because the elytra of insect prevent insecticide to contact with the cuticle of insect.

\section{CONCLUSION}

The results of this study indicate that the botanical pesticides used to control the important aphids of citrus orchards, had a desirable level. Also, according to the results, Palizin 2 and $2.5+$ Citrol oil $5 \mathrm{ml} \mathrm{l}^{-1}$ and Tondexir concentrations with Bartar soap and also Dayabon $10 \mathrm{ml} \mathrm{l}^{-1}$ treatment, in addition to effective control on the citrus aphids, had a negative effect on the seven-spotted ladybird which is the most important natural enemy in citrus orchards. So, they could be a good alternative to other high-risk chemical insecticides.

\section{ACKNOWLEDGEMENTS}

This work was supported by the Entomology section of the Department of Plant Protection of Shahed University, Tehran, and Sari Agricultural Sciences and Natural Resources University, Iran.

\section{REFERENCES}

Alam, M. Z., Alam, M. S. \& Abbas M. (1972). Status of different stem borers as pests of rice in Bangladesh. IRRN, 21(2), 15-17.

Chen, R. z., Li, X. y., Liu, M., Yi, B. r., Sheng, C. f. \& Ma, J. y. (2007). A preliminary study on generation of Chilo suppressalis (Walker, 1863) in Changchun City using sex pheromone technique. Journal of Jilin Agricultural Sciences, 32, 37-39.

Abbasipour, H. \& Basij, M. (2016). Identification and control of citrus pests. Applied Higher Education Institution of Agricultural Jihad, pp. 89-94.

Ali, A. \& Rizvi, P. Q. (2010). Age and stage specific life table of Coccinella septempunctata L. (Coleoptera: Coccinellidae) at varying temperatures. World Journal of Agricultural Sciences, 6(3), 268-273.

Amiri-Beheshti, B. (2009). Toxicity evaluation of Tracer, Palizin, Sirinol, Runner and Tondexir with and without min- 
eral oils on Phyllocnistis citrella Stainaton. African Journal of Biotechnology, 8, 3382-3386.

Anonymous. (2015). Environmentally friendly pesticides. Available from: http://www.kimiasabzavar.com

Ansaripour, A., Aghasi, K. \& Bedoreh, M. (2012). Density and sex ratio of seven spotted ladybird (Coccinella septempunctata) in three altitudes of Khorramabad district. Life Science Journal, 9, 830-834.

Baniameri, V. (2008). Study of efficacy of different concentrations of insecticidal soap, in comparison oxydemetonmethyl to control Aphis gossypii in greenhouse cucumber. IOBC/wprs Bulletin, 32, 13-16.

Barjadze, S., Kvavadze, E., Kvavadze, E. \& Tsertsvadze, R. (2009). Food spectrum of Coccinella septempunctata L. (Coleoptera, Coccinellidae) in the urban habitats of Tbilisi (Georgia). Revue Francaise de Entomologie (N.S.), 31(1), 30-32.

Campbell, C. D., Walgenbach, J. F. \& Kennedy, G.G. (1991). Effect of parasitoids on lepidopterous pests in insecticidetreated and untreated tomatoes in Western North Carolina. Journal of Economic Entomology, 84(6), 1662-1667. https://doi.org/10.1093/jee/84.6.1662

Cavalloro, R. \& Martino, E.D.I. (1985). Integrated Pest Control in Citrus Groves. Proceedings of the Expert's Meeting, Acireale, 26-29 March 1985, published for the European communities, $599 \mathrm{p}$.

Heydari, S., Toorani, A.H. \& Abbasipour, H. (2016a). Comparison of Plant and Chemical Pesticide Effects on Aphis nerii Boyer de Fonscolombe (Hem.: Aphididae). The $5^{\text {th }}$ Congress of Agriculture and Sustainable Natural Resources, Tehran, Iran, https:// www.civilica.com/Paper-NACONF05NACONF05_084.html

Heydari, S., Toorani, A.H., Dostarkalkenari, L. \& Abbasipour, H. (2016b). Comparison effects of botanical pesticides on first instar nymphs of the citrus cushion, Pulvinaria aurantii Cockerell and its ladybird predator, Cryptolaemus montrouzieri Mulsant. 22 ${ }^{\text {nd }}$ Iranian Plant Protection Congress, Tehran, Iran.

Heydari, S., Toorani, A.H., Dostarkalkenari, L. \& Abbasipour, H. (2016c). Comparison effect of botanical pesticides on first instar nymphs of the Australian mealybug, Icerya purchasi Maskell and its ladybird predator, Novius cardinalis Mulsant. 22 $2^{\text {nd }}$ Iranian Plant Protection Congress, Tehran, Iran.

Honek, A. \& Martinkova, Z. (2005). Long term changes in abundance of Coccinella septempunctata L. (Coleoptera: Coccinellidae) in the Czech Republic. European Journal of Entomology, 102(3), 443- 448. https://doi.org/10.14411/ eje. 2005.063

Imani, A. \& Toorani, A. H. (2016). Study of the Effect of Plant and Chemical Pesticides on Citrus Aphis citrus, Aphis citricola V. d. G (Hem.: Aphididae). $3^{\text {rd }}$ International Conference on Sustainable Development, Solutions and Challenges Focusing on Agriculture, Natural Resources, Environment and Tourism, Tabriz, Iran, https://www. civilica.com/PaperICSDA03-ICSDA03_002.html

Jacas, J.A., Karamaouna, F., Vercher, R. \& Zappala', L. (2010). Citrus pest management in the northern Mediterranean basin (Spain, Italy and Greece). In: Ciancio A, Mukerji KG (eds.) Integrated Management of arthropods pests and insect borne diseases. Springer, NL. Dordrecht, the Netherlands, pp 3-27. https://doi.org/10.1007/978-90-481-8606-8_1

Kabiri, M., Amiri-Beheshti, B. \& Basirat, M.A. (2012). Comparison of toxicity of the botanical insecticide, Sirinol and two chemical insectides, Mospilan and Consult, in two natural enemies of the pistachio psyllid, coccinellid predator (Oenopia conglobate) and parasitic wasp (Psyllaephaus pistaciae). African Journal of Biotechnology, 11, 13888-95. https://doi.org/10.5897/AJB11.4159

Kazem, M.G. T. \& El-Shereifi, S.A.E.H.N. (2010). Toxic Effect of Capsicum and Garlic Xylene Extracts in Toxicity of Boiled Linseed Oil Formulation against some Piercing Sucking Cotton Pests. American- Eurasian Journal of Agricultural \& Environmental Science, 8, 390-396.

Lapchin, L., Gtrvot, H. \& Brun, P. (1994). Spatial and temporal heterogeneity in population dynamics of citrus aphids at a regional scale. Ecological Research, 9, 57-66. https://doi. org/10.1007/BF02347242

Matthews, G.A. (1999). Pesticides, IPM and training. Phytoparasitica, 27, 253-256. https://doi.org/10.1007/BF02981480

Potter Precision Spray Tower (2000). Burkard Manufacturing Co. Ltd. http://pollenuk.worc.ac.uk/Burkard/ Default. html.

SPSS Institute.(2006). SPSS Base 15.0 for Windows, User's Guide Computer Program Version by SPSS Inc., Chicago, IL.

Sterk, G., Heuts, F., Merck, N. \& Bock, J. (2003). Sensitivity of non-target arthropods and beneficial fungal species to chemical and biological plant production products results of laboratory and semi-field trials. p. 306-313. In: Proc. 1st International Symposium on Biological Control of Arthropods, Honolulu, Hawaii, USA, 14-18 January 2002, 532 pp.

Suma, P., Zappala', L., Mazzeo, G. \& Siscaro, G. (2009). Lethal and sublethal effects of insecticides on natural enemies of citrus scale pests. Biocontrol, 54, 651-661. https://doi. org/10.1007/s10526-009-9215-Z

Tena, A. \& García-Marí, F. (2011). Current situation of citrus pests and diseases in the Mediterranean Basin. IOBC/ WPRS Bulletin, 60, 349-361.

Toorani, A.H. \& Abbasipour, H. (2016). Study of the Effect of Plant and Chemical Pesticides on Citrus Aphids, Toxoptera aurantii B.d.F (Hem.:Aphididae). $3^{\text {rd }}$ Conference on New Findings in the Environment and Agricultural Ecosystems, Tehran, Iran, https://www.civilica.com/Paper-AGROCONGRESS03- 459.html

Toorani, A. H., Abbasipour, H. \& Doostdar Kalkenari, L. (2017). Toxicity of selected biorational insecticides to Pulvinaria aurantii Cockerell and its predator, Cryptolaemus montrouzieri Mulsant in citrus field, Acta Agriculturae Scandinavica, Section B-Soil \& Plant Science, 67(8), 723-729. https://doi.org/10.1080/09064710.2017.1338745

Urbaneja, A., Catalán, J., Tena, A. \& Jacas, J.A. (2012). Gestiónintegrada de plagas de cítricos. http://www. gipcitricos. ivia.es.

Zappala', L. (2010). Citrus integrated pest management in Italy. In: Ciancio A, Mukerji KG (eds.) Integrated management of arthropods pests and insect borne diseases. Springer, Dordrecht, pp 3-27. https://doi.org/10.1007/978-90-4818606-8_4 